\title{
"The squeaky wheel gets the grease"? The conflict imperative and the slow fight against environmental injustice in northern Peruvian Amazon
}

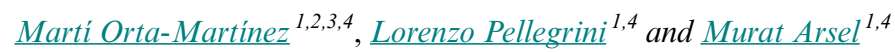

\begin{abstract}
We chronicle a four-decades-long struggle that has been taking place in the Peruvian Amazon between indigenous groups, oil companies, and the state. We provide a broad overview of the strategies of the communities in the area, juxtaposing the outcomes of different negotiating strategies. In addition to documenting what is an especially important case of socio-environmental conflict in the Peruvian Amazon, we go beyond the dominant approach in the literature, which sees dialogue as inherently desirable and conflict as necessarily unwelcome, and describe the Achuar decision to engage in open conflict with the oil company as one that testifies to the existence of a conflict imperative. In other words, the overcoming of environmental injustice in certain circumstances requires various forms of direct action that take grievance and complaint to the level of open conflict. The corollary of this hypothesis is that dialogue is sometimes neither peaceful nor useful for affected communities. This calls for a rethinking of the boundaries between conflict and negotiation. In our chronicle, conflict itself was often the antecedent to a new round of dialogue and negotiation made possible by the presence of government officials purposively and urgently dispatched to the area. Echoing Clausewitz's famous dictum concerning the continuity between war and policy, indigenous decisions to occupy, blockade, and disrupt the working of oil operations might tentatively be understood as an attempt to continue negotiating with the state and corporations by using other tools they have at their disposal.
\end{abstract}

Key Words: Achuar; Amazon; extractive industry; indigenous people; Kichwa; oil extraction; Quechua; socio-environmental conflicts

\section{INTRODUCTION}

On 10 October 2006, more than 800 indigenous people from the Achuar community of the northern Peruvian Amazon occupied the facilities of the country's longest operating and most productive oil project (blocks 8 and $1 \mathrm{AB} / 192$ ). This dramatic action could not have been a surprise to many because about a week prior to the occupation, they released this strongly worded statement: "For many years we have tried to dialogue with companies and governments, and nevertheless nothing has changed, and contamination continues." Denouncing "the mockery of the Ministry of Energy and Mines [MEM]" and the "malicious way" in which a commission that was set up to deal with the issue of oil-related pollution was operating, they demanded that the authorities begin "a serious dialogue [...] with our indigenous authorities that legitimately represent us, take immediate measures to stop pollution and attend to indigenous people ill from lead, cadmium and other oil-related pollutants." Signalling their intention to take concrete action, their declaration left no room for misinterpretation: "Now the Achuar stand up and serenely but firmly say that enough is enough. We ourselves will stop pollution in our communities. We will act in legitimate defence of our rights" (FECONACO 2006).

At the heart of their action was a simple demand: that the government and the oil company, Pluspetrol, should agree to reinject the most toxic by-product of oil extraction known as formation or produced water in the oil field. ${ }^{[1]}$ This was not a particularly radical demand because it essentially amounted to an expectation that the government would no longer grant exceptions to the company to avoid complying with existing Peruvian laws. ${ }^{[2]}$ Nor was the occupation a hasty, impetuous move on the part of the Achuar. The action came after more than three decades of attempts at dialogue and negotiation. By occupying the production facility, the Achuar decided to challenge not only the wilful negligence of the oil company they also confronted the inability or unwillingness of the Peruvian state to enforce its own laws or to protect the well-being of its indigenous communities. More importantly, the Achuar were changing their strategy, abandoning, at least temporarily, a long and frustrating process of attempting bona fide dialogue and negotiation for a very different approach, that of open, escalated conflict. We focus on this decision and its implications for our understanding of conflict's utility for communities as a means of engagement with state and corporate actors. In addition to documenting what is an especially important case of socio-environmental conflict in the Peruvian Amazon, we also go beyond the dominant approach in the literature, which sees dialogue as inherently desirable and conflict as necessarily unwelcome by building on the recognition that "[d]issent and conflict, can ... produce productive and creative solutions for intractable problems" (Swyngedouw 2006:73, Silva 2017).

We describe the Achuar decision to engage in open conflict with the oil company as one that testifies to the existence of a "conflict imperative." In other words, the overcoming of environmental injustice in certain circumstances, such as the ones that characterize the case discussed here, cannot be possible through a process of dialogue and negotiation and also requires various forms of direct action that take grievance and complaint to the level of open conflict. The specific conditions in this case can be summarized as the prevalence of corporate impunity that resulted in widespread socio-environmental liabilities and governmental inability and/or unwillingness to take necessary regulatory and punitive actions. Framed within the debate on conflict, cooperation, and natural resources, our case study shows how conflict can, in these particular conditions, contribute to enhancing social-ecological resilience. Despite our argument that to achieve progress in such conditions it is imperative for communities to engage in open conflict, the picture we draw is nuanced. Although conflict (actual and potential) can be

${ }^{1}$ International Institute of Social Studies (ISS), Erasmus University Rotterdam, ${ }^{2}$ University of Vic-Central University of Catalonia, ${ }^{3}$ Institute of Environmental Science and Technology (ICTA), Autonomous University of Barcelona, ${ }^{4}$ Instituto de Geografía, Universidad San Francisco de Quito 
instrumental in overcoming entrenched power imbalances, the act of engaging in conflict as well as the responses of adversaries (such as the state or the corporation) can be very costly.

The first author has been engaging with action-oriented participatory research with some of the main protagonists of this paper over the past 13 years. The other authors have been working in the area for five years. Taken together, the main thrust of their activities has been to support the development of independent, community-based socio-environmental monitoring systems to document the socio-environmental impacts of oil operations in the study area. This paper is built on qualitative panel data covering five decades of oil extraction in the area. That is, our approach is to tackle a case study through historical lenses, a choice that stands in contrast with most case studies that provide a snapshot of conflict or cooperation around natural resources and also in contrast with cross-sectional studies that provide atemporal examinations of average relationships. The temporal dimension of our study is in fact key to our findings, in particular concerning the cyclical nature of conflict and dialogue and to the questioning of conflict and cooperation as dichotomous categories.

Research methods to collect information included participant observation, with extensive and repeated stays in the field, several single- and multistakeholder workshops, formal and informal interviews. The authors have also consulted primary and secondary literature and data, as indicated also in the reference list. Although the authors' primary concern and contacts are located within local communities and with their representatives and organizations, they have extensively engaged also with broader stakeholders at various scales. Thus, interviews and discussions took place also with the community relations staff and other workers of oil companies, local companies, and entrepreneurs providing goods and services to the oil complex, local governments, state agencies in charge of enforcement of environmental regulations, as well as, agencies in charge of promoting investment in the energy sector.

\section{NATURAL RESOURCES, STRUCTURAL VIOLENCE, AND CONFLICT}

For the purposes of this paper, conflict is best understood as the (temporary) breakdown of a variety of political, policy, or bureaucratic processes based on dialogue, e.g., negotiation between state and indigenous actors, and their (once again, temporary) replacement with various forms of direct action, e.g., occupation of an oil field. In broader terms, our definition is compatible with Kriesberg's: "a relationship between two or more parties who believe they have incompatible goals" (1973:17). In order to fully articulate our argument regarding the potential utility of conflict, we focus on conflicts between indigenous communities on one side and state and corporate actors on the other. This analytical choice is made with the full recognition of the reality that none of these actors are monolithic entities and that they are prone to internal conflicts themselves.

Within mainstream policy circles, conflicts over natural resources are generally assumed to be anathema to the goals of achieving sustainable development. High level initiatives such as the Environmental Change and Security Program (https://www. wilsoncenter.org/event/innovative-partnerships-for-peace-the-roleextractive-industries-resource-based-conflict) or The EU-UN
Partnership on Land, Natural Resources and Conflict Prevention (http://www.un.org/en/land-natural-resources-conflict/extractiveindustries.shtml) are essentially built around the argument that dialogue and conflict resolution practices are inherently superior to conflict, based on the implicit assumption that bona fide dialogue is always possible. This view sees the challenge in conflictive situations primarily as a processual one in which the task is to keep conflicting parties engaging each other with a view to reaching a new status quo in which the shared interests of the parties trump their differences. This argument itself is built around the assumption that the interests of conflicting parties are essentially reconcilable and that win-win solutions are attainable. Some scholars argue, however, that win-win solutions are the driving ideology of contemporary neoliberal attempts to diffuse the tension between nature, society, and capitalism (Arsel and Büscher 2012). The view of conflict as an unqualified evil also rests on the implicit assumption that conflict and dialogue are two dichotomous categories that exclude each other.

Although it is not the goal of this paper to provide an archaeology of the approach to natural resources and conflict in the mainstream policy circles, it is important to note that this "getting to yes" (Fisher and Ury 2011) approach to dialogue has been an essential component of the neoliberal orthodoxy and, for example, it is reflected in the emphasis given to consultation over extractive projects (Pellegrini 2012, Pellegrini and Ribera Arismendi 2012, Schilling-Vacaflor and Eichler 2017). The ultimate implication of this approach is to render conflicts apolitical by denying the potentially incompatibility of interests, e.g., based on different class positions, or incommensurability of value systems. Although this approach has limited use even within the confines of liberal democracies (Hirschman 1994), it is especially problematic in a setting such as the Peruvian Amazon where state capability is weak and corporate sway especially strong (Stetson 2012, Siegel 2016).

At first sight, the resource curse literature might seem suitable for understanding conflict dynamics in such settings. This literature, which dominates the study of the relationship between nonrenewable natural resources and conflict focuses on conflicts at the national or regional level, i.e., armed conflicts, separatist conflicts, terrorism, etc. The main thrust of this literature has been to explain how the existence of natural resource wealth leads to conflicts over the (potential) wealth that can be generated from its extraction. The proponents of the resource curse thesis seek to demonstrate that the existence of rich resources creates a number of mechanisms through which development processes are undermined (Auty 2002, Papyrakis and Gerlagh 2004, Robinson et al. 2014). However, this body of work suffers from a similar weakness, namely that it is organized around the notion that conflicts are damaging for the interests of the parties involved and therefore in fundamental tension with the overall goal of development.

There exists an alternative approach with a large body of literature scrutinizing the genesis of resistance movements within contexts of resource-related conflicts. These are, almost by definition, concerned with local dynamics. One major strand within this tradition aims at understanding how communities resist and articulate their demands for change. The approach is primarily one of social movement studies and to the extent that national 
and global scales enter into a discussion, it is to document the alliances and appeals made by movements (see, for example, Keck and Sikkink 1999, Muradian et al. 2003).

Another strand seeks to explain why communities choose to resist and engage in open conflict. Unlike the resource curse literature and its related strands such as "greed and grievance," the innovative aspect of this scholarship has been to recognize that local communities bear greater pollution burdens and costs and to redefine externalities not as market failures but cost-shifting successes of the economy of unpaid costs (Martínez-Alier 2002, Walker 2009, Fletcher 2010). Seen from such a perspective, environmental impacts of oil extraction cannot be seen as accidental outcomes and indigenous communities as unwitting victims who merely need to appeal to the corporations and state agencies to alleviate their suffering. Instead, the literature portrays such situations as those of fundamental tension between the interests of those who own and live in territories where natural resources are located and those who seek to extract them, echoing Kriesberg's definition of conflict mentioned above. Ultimately, the most important contribution of this strand of literature is to empirically demonstrate that the absence of conflict does not equate with justice and effective peace.

This is of course not a new argument. Tacitus, almost 2000 years ago, commented on the structures of the Roman Empire and the Pax Romana: "To ravage, to slaughter, to usurp under false titles, they call empire; and where they make a desert, they call it peace" (Tacitus 2009). The contribution of this new literature has been to demonstrate how within the broad historical and structural dynamics of capitalism, socio-environmental impacts of economic development processes can be equally devastating (Arsel 2011). For example, Michael Watts examining famines in sub-Saharan Africa, and questioning fundamentally the notion of natural disasters, has introduced the concept of "silent violence" (Watts 2013), which does not necessarily ignite open conflict. In a similar vein, Galtung introduced the concept of "structural violence," referring to broad forms of violence that do not originate in the actions of a single person or organization, but rather from social structures (Galtung 1969). Finally, Nixon has dealt with a similar phenomenon, "slow violence" (Nixon 2011), one that creates extensive social and environmental damage without ever creating the type of spectacle that can harness (inter) national outcry and attention.

In this paper, we build on this approach and on Hirschman's argument that it is potentially mistaken to view conflicts as "dangerous, corrosive, and potentially destructive of social order and therefore ... in need of being contained and resolved ..." (1994:206). Conflicts can be productive and can, at least partially, address the structural inequalities between communities and powerful state and corporate actors, alleviating some of the effects of slow violence inflicted upon them.

The empirical backdrop to this argument comes from our chronicling of the environmental injustice faced by Achuar, Kichwa, and Quechua communities of the northern Peruvian Amazon in the form of this type of silent, structural, and slow violence. We argue that conflict is not only fostered by the operations and abuses of oil industry and the lack of redress through state-mechanisms, but also that in this context conflict is actually necessary to prompt the company and the state to undertake the adequate steps to mitigate the environmental and health impacts of oil extraction. By presenting the evolution of this conflict, we show that open conflict has precipitated changes in the oil industry's operational procedures and standards and improvements in its socio-environmental performance. Yet, the story is complicated by our data, which shows that oil companies have deployed strategies to break communities' resistance to oil extraction and resulted in new deliberately inflicted impacts that affected communities in novel ways.

\section{DIALOGUE, DELAY, AND FRUSTRATION}

In the northern Peruvian Amazon, oil concessions known as Block 8 and Block 1AB (now 192) were leased in 1969 and 1971 (Fig. 1). These concessions overlap with the Corrientes, Pastaza, Tigre, and Marañón river basins. The oil blocks were first held by PetroPerú (the Peruvian national oil company) and Occidental Petroleum Corporation (a U.S.-based company commonly referred to as $\mathrm{OXY}$ ), then transferred to Pluspetrol del Norte $\mathrm{S}$. A. (a seemingly transnational company, whose headquarters and the nationality of its main shareholders are hard to trace) in 1996 and 2001. In August 2015 the 1AB/192 concession expired and a new contract was signed with Pacific Stratus Energy, a subsidiary of Toronto-based Pacific Rubiales Energy/Frontera Energy Corporation. These oil blocks have become the longest running oil projects in the Peruvian rainforest and the most productive in Peru (Orta-Martínez and Finer 2010), with an accumulated production of 1032 million barrels $(39.2 \%$ of total national oil production; MEM 2014).

More than 45,000 indigenous people live in these river basins (Instituto del Bien Común 2016). Since the 1990s, these indigenous people are represented by several indigenous federations: the Achuar Federation of Native Communities of the Corrientes River (FECONACO), the Kichwa indigenous organization of the Peru-Ecuador border (OPIKAFPE), the Kichwa Federation of Native Communities of the Tigre River (FECONAT), the Quechua Indigenous Federation of the Pastaza River (FEDIQUEP), and the Kukama Association for the Conservation and Development of San Pablo de Tipishca (ACODECOSPAT). In this paper, we will focus mainly on Block $1 \mathrm{AB} / 192$, overlapping with the traditional territories of the Achuar, Kichwa, and Quechua people.

The negative environmental and public health impacts of oil extraction have been identified and extensively documented by various Peruvian state agencies since the early days of the oil field (Orta-Martínez et al. 2007, Yusta-García et al. 2017). Statesanctioned documents have reported cadmium and lead in fish above acceptable limits for human consumption (Cánepa et al. 1987), hexavalent chromium (Maco et al. 1985), hydrocarbons, barium, lead, mercury, and chlorides in rivers and river sediments above the Peruvian maximum permissible limits (MEM 1998), and "presence of visible petroleum spills in different places" (OSINERG 2004:16). In 2005, the Ministry of Health found that $98.6 \%$ and $66.2 \%$ of Achuar children $2-17$ years of age exceeded the acceptable limits for cadmium and lead in blood, as well as $99.2 \%$ and $79.2 \%$ of adults (DIGESA 2006). In 2013, the Peruvian government declared an environmental state of emergency, and later on, in 2014, a health emergency in the Pastaza, Corrientes, Tigre, and Marañón river basins. The discharge of 1 million barrels/day of toxic produced water on soils and rivers in the area 
has been an especially important driver of these and other serious impacts (Orta-Martínez et al. 2018, Rosell-Melé et al. 2018). Consequently, the manner in which this produced water is disposed of has been one of the main targets of indigenous social mobilization.

Fig. 1. Map of Block 1AB/192 and Block 8 oil concessions and titled indigenous territories in the northern Peruvian Amazon. Own elaboration with GIS data from Perupetro (oil concessions) and the Peruvian Ministry of Agriculture (titled indigenous lands).

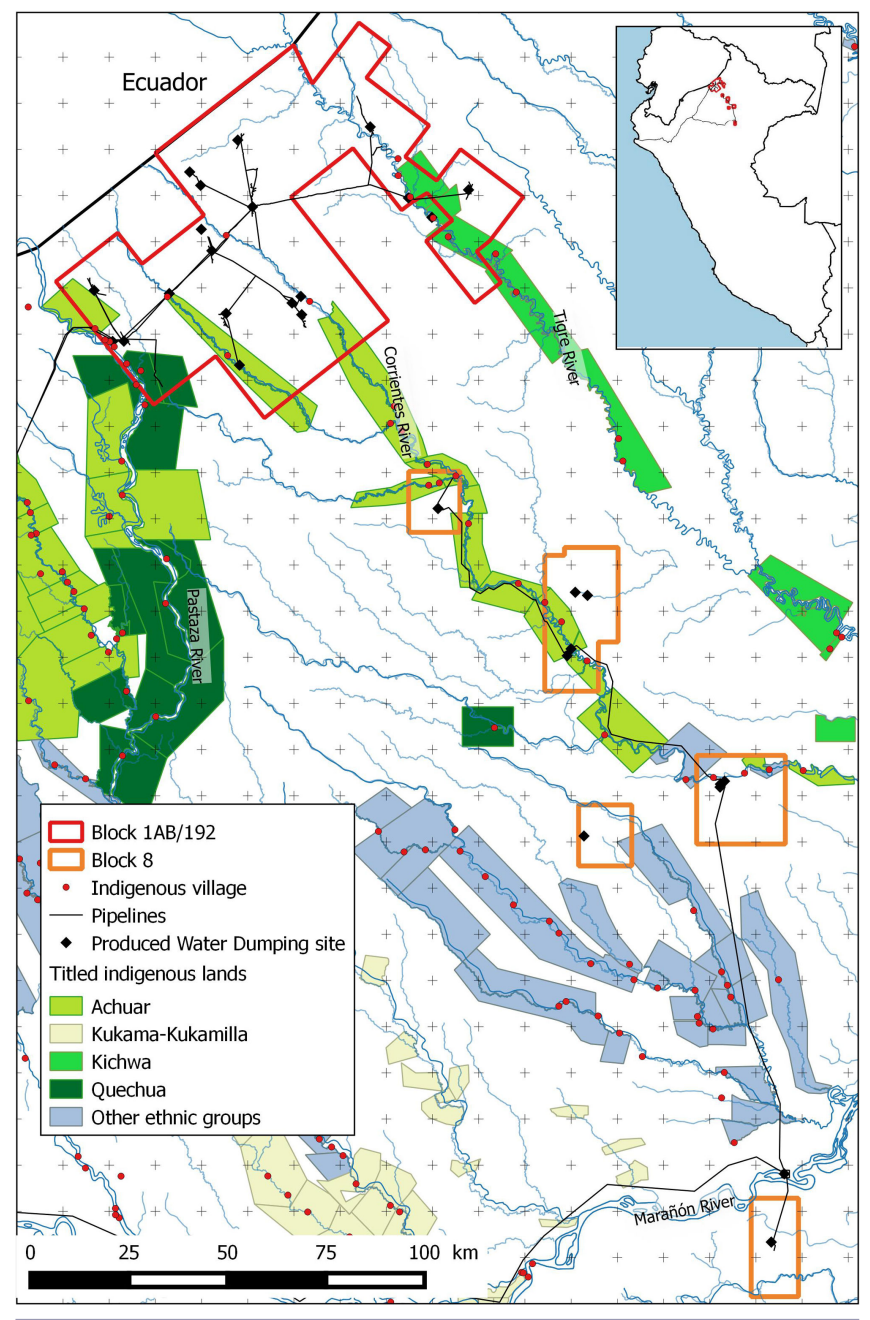

\section{Land rights and health impacts in indigenous communities}

Unsurprisingly, the negative impact of oil activities in the region went beyond public health concerns. Though the violation of indigenous rights was multifaceted and multifarious, the first instances engendering discontent among the Achuar were limited to the fact that they were, in some cases, displaced to build oil infrastructure (pipelines, drilling sites, roads, oil camps, etc.) and lost control of their ancestral territories. Thus, in 1978 three Achuar leaders, with the support of two Austrian anthropologists, Elke Mader and Richard Gippelhauser, travelled to Iquitos to demand respect of their territorial rights and to stop the oil activities in their territories (Uriarte 2007). Helped by the Cousteau Society and the Spanish anthropologist L. M. Uriarte, they managed to have a meeting on 12 August 1983 with the Peruvian President, Fernando Belaúnde Terry.

This started a four-decade long odyssey for the Achuar to safeguard their rights, which proved to be an exhausting journey through the bumbling Peruvian bureaucracy. Meanwhile, while the Kichwa and the Quechua experienced similar impacts, their complaints and opposition went unnoticed beyond the local communities. In fact, during the 1970 s and 1980s, the Kichwa and the Quechua did not mobilize in ways that were visible outside local communities and oil operations took place unchallenged by organized resistance. It was only in the 1990s that Kichwa and Quechua federations joined in the overall struggle. Together, they embraced an array of strategies looking for state interlocutors and mechanisms to redress their situation. Below we discuss them under two separate but clearly related attempts to have their land rights and their public health concerns recognized.

\section{Navigating the bureaucracy of land titling}

The Achuar of the northern Peruvian Amazon focused from the beginning of their struggle on the legal recognition of their territory. Their practice and strategies reflected an early emerging consensus, sanctioned in the UN system only in 2007, that the "control by indigenous peoples over developments affecting them and their lands, territories and resources will enable them to maintain and strengthen their institutions, cultures and traditions ..." (Surrallés and Garcia-Hierro 2004, UN 2007). The expectation was that land titles would create security of land tenure and contribute to effective control over territory to confront oil operations.

Although the Achuar attempts to secure territorial rights date back to their meeting with the Peruvian President in 1983 (Uriarte 2007), so far they have only achieved titles on a fraction of their land claims. There was no progress on this issue during the $1980 \mathrm{~s}$ and only in the 1990s, when a land titling program was set up by the Peruvian Agriculture Department, the Special Project on Land Titling funded by the World Bank in 1991, the Achuar, Kichwa, and Quechua managed to get fragmented communal land titles for some of their settlements, covering a small portion of their ancestral territories (see Fig. 1).

Furthermore, even when officially granted, these land titles do not guarantee meaningful control over territory. For example, land ownership does not include forest rights and the state can lease logging concessions overlapping with community titles, tenure is limited to surface rights, and right-of-way has to be given for all state-constructed roads and to oil or gas pipelines, among other infrastructure (Stocks 2005).

In the 2010s the Achuar, Kichwa, and Quechua are still struggling to get their ancestral territories titled. The Achuar resorted to filing fresh official complaints to the Regional Government of Loreto in 2011 (Servindi 2014), the Peruvian Congress in September 2011 (Radio Oriente 2011), and twice to the InterAmerican Commission on Human Rights (IACHR) at the 146th regular session in 2012 and the 153rd session in 2014. Finally, in April 2015, and after years of preparation, the Achuar filed a claim against the Peruvian government before the First Level Court in Iquitos demanding the legal titling of the whole of their 
ancestral integral territory. Because the court did not admit the claim, the Achuar appealed to the Superior Court in November 2015. Concurrently, in May 2015, FECONACO, FEDIQUEP, and ACODECOSPAT filed an "action of protection" (acción de amparo) to the Nauta Court (admitted in July 2015) against the easement and demanding the titling of all of their territories ${ }^{[3]}$.

Indigenous peoples have often alleged that the Peruvian government employs Byzantine bureaucratic procedures as a strategy to stonewall their quest for land titles. Indigenous communities in Peru have to self-finance their titling efforts and had to "navigate their way through corruption ... [and] over 27 bureaucratic procedures" to obtain official recognition and formal land titles, a costly process that can take more than a decade (AIDESEP and Rainforest Foundation US 2015:12). As a result, indigenous communities formally own 15 million hectares of the Peruvian Amazon, but there are "a further 20 million hectares of pending indigenous land titling applications unanswered by the Government" and only 50 indigenous land titles have been approved in the period 2007-2014(AIDESEP and Rainforest Foundation US 2015:10).

\section{The right to a safe and healthy environment}

Beyond unwavering demands for their territorial rights, the Achuar, Kichwa, and Quechua people have also reported systemic and widespread violations of their right to a healthy environment (sanctioned by Article 29 of the UN declaration on the rights of indigenous people) and life. In particular, increasing mortality, cancer, and other illnesses including allergic reactions of the skin and eyes have been reported and attributed to acute cases of oilrelated poisoning (La Torre López 1998, San Sebastián et al. 2001, 2002, Hurtig and San Sebastián 2002, 2004, Jobin 2003, OrtaMartínez et al. 2007, 2018, Álvarez-Alonso 2008, O'CallaghanGordo et al. 2016).

To tackle this situation, they have pursued a number of initiatives over the 1990s, 2000s, and 2010s. In 1993, after participating in the FECONAT General Assembly, the Regional Government of Loreto agreed to create an Environmental Commission to assess the environmental impacts of oil activities. In the same meeting, OXY promised to drill 15 water wells to supply safe drinking water to the indigenous communities. However, both the Regional Government and OXY failed to fulfil their already rather modest promises (La Torre López 1998). In October 1996, Mr. Fabriciano Sangama Napuchi, who later became the mayor of the District of Trompeteros, started an unsuccessful lawsuit on water pollution against OXY and Petroperú (La Torre López 1998). In the same year, FECONACO requested a commission composed of the Ombudsman (Defensor del Pueblo del Perú), the Congress of the Republic, ILO, AIDESEP, and FECONACO to assess the environmental situation of the Corrientes River. FECONAT, FEDIQUEP, and FECONACO asked state authorities, also in 1996, to declare the area an environmental emergency and to implement an Environmental Remediation Plan (La Torre López 1998). That same year, Alianza Capahuari, one of the Quechua communities, sent an appeal to the Peruvian President, the Ministry of Energy and Mines (MEM), and the Peruvian Congress calling for their intervention to address the environmental problems engendered by the dumping of produced water. The Commission for the Amazon, Ecology, and Environment from the Peruvian Congress, requested an answer from the MEM. The response, based on the environmental selfmonitoring reports that oil companies have to submit on a monthly basis to the Energy Ministry, noted that the discharges did not exceed the maximum permissible limits for any pollutant.

During the following years and until 2006, the Achuar, Kichwa, and Quechua people held numerous meetings with three different commissions from the Peruvian Congress, the General Direction for Environmental and Energy Affairs (DGAAE) from the MEM, the Minister of Health, the Environmental Health Agency (DIGESA), the Regional Health Directorate of Loreto (DIRESA-Loreto), the General Office of Epidemiology (OGE), and other state agencies (Orta-Martínez and Finer 2010). After more than two decades of meetings in Iquitos and Lima (selffinanced by the indigenous organizations), several visits of government missions took place in the $1 \mathrm{AB} / 192$ and 8 oil blocks (CAAIA 2005). As a result of these missions, public authorities published a number of reports identifying severe pollution and calling on the Peruvian Government to take action. However, no concrete action was taken.

OSINERG (the regulating body for energy, hydrocarbon, and mining activities) visited the area for inspection in 2002 for the first time. Five inspections carried out during 2002-2003 resulted in 264 observations in the $1 \mathrm{AB} / 192$ oil block (OSINERGMIN 2009). Most of the observations showed dumping of produced water with levels of contamination above maximum permissible limits, the inadequate remediation of polluted sites, and the fact that the compulsory monthly self-monitoring reports that Pluspetrol have to submit to the MEM were not truthful because the produced water outlets were not in the locations declared by the company. Several administrative procedures started as a consequence of these observations, resulting in the temporary closure (between 4 and 12 months) of 24 oil wells in 2005, and several fines. A new inspection in June 2006 also resulted in another administrative procedure (OSINERGMIN 2009). However, Pluspetrol decided to sue OSINERGMIN and, to date, has paid only one of the fines.

The DIGESA mission from July 2005 deserves special attention because it is often considered the tipping point in terms of strategies of indigenous groups to deal with the impacts of oil extraction. On 2 May 2005 the Achuar people from the Corrientes River filed a petition asking to urgently conduct "analysis of blood, urine, nail, and hair samples of villagers from the Trompeteros district to verify the presence of heavy metals and prevalence of oil-related diseases" (FECONACO 2005a). As a result, a health assessment was carried out from 29 June to 15 July 2005 and the results published in May $2006^{[4]}$. The study found alarming results, showing that $98.65 \%$ and $66.21 \%$ of children exceeded the acceptable limits for cadmium and lead in blood, respectively, as well as $99.20 \%$ and $79.20 \%$ of adults (DIGESA 2006). However, again no action was taken in response to the report.

Further aggravating this situation, between 2004 and 2007 the Peruvian government leased six new oil concessions overlapping the whole Achuar, Kichwa, and Quechua ancestral territories: blocks 101 (Talisman), 102 (Ramshorn), 104 (Burlington), 106 (Petrolífera Petroleum), 127 (Cepsa), and 143 (Hunt Oil; OrtaMartínez and Finer 2010). As a result of this situation, in November 2005, the FECONACO General Assembly of the 
Achuar people issued a statement declaring that they do "not accept more oil operations in their territory" expressing total opposition to the expansion of the oil industry for the first time (FECONACO 2005b).

\section{THE CONFLICT IMPERATIVE}

As mentioned above, state agencies gathered sufficient evidence of severe pollution and environmental malperformance of the oil industry in blocks $1 \mathrm{AB} / 192$ and 8 , essentially confirming the local knowledge on the impacts of oil extraction. Nevertheless, indigenous peoples of the northern Peruvian Amazon experienced almost three decades of disappointment as they remained stuck in the impasse created by the Peruvian state. They often allege that the Peruvian government uses a strategy of tiring them by periodically inviting them to go to faraway Lima to have talks that do not lead to concrete action (Orta-Martínez and Finer 2010).

In January 2005, in light of the breach of a community-company agreement to provide electricity and drill water wells, the residents of the Achuar community of Nueva Jerusalén decided to march and block the oil road between the central production facilities of Dorissa and Huayuri. To our knowledge, it was the first time the Achuar employed direct action at the community level. After the commitment of the company, in writing and signed by the Community Relations Manager, Mr. Javier Pastor, mobilization was called off. In June 2005, after the mutually agreed deadline had passed, the community blocked the road again for three days. This time, the Operations Manager, Mr. Luis Canales, signed a new written commitment (FECONACO 2005c).

\section{The Dorissa Accords}

The situation came to a head during 2006. As mentioned above, the alarming health study conducted by the DIGESA that found extremely high cadmium and lead blood levels was published in May 2006. A Health Action Plan was designed in June 2006, but no budget was assigned to it. In meetings held in Lima at the beginning of September 2006, the Peruvian government committed to create a multisector commission to improve the socio-environmental conditions of their territories in oil blocks $1 \mathrm{AB} / 192$ and 8 . The indigenous leaders were invited to a new meeting in Iquitos on 26 September to kick-off the commission. Achuar leaders travelled for several days from their communities to Iquitos to attend this meeting, but no officials showed up. The indigenous leaders, feeling offended and cheated, marched through the streets of Iquitos. Eventually, the kick-off meeting took place on 3 October. However the officials just met indigenous leaders from FEPIBAC (Federation of Indigenous Peoples of the Low Corrientes), an "astroturf" organization known in the region to be receiving funds from the oil companies to create dissent within the Achuar indigenous groups (Isla 2009, Lu 2009, OrtaMartínez and Finer 2010, Scurrah 2013). This was further aggravating for the Achuar people and the declaration and ensuing occupation discussed in the introduction was the outcome.

The blockade was effective and the Achuar succeeded in enforcing international environmental standards and the provisions of national legislations, a feat that seemed to have been outside the reach or the will of the Peruvian state. The outcome was codified in what is known as the Dorissa Accords. Accordingly, Pluspetrol asked permission from the MEM to modify the environmental management programs to reinject all the produced water in blocks $1 \mathrm{AB} / 192$ and 8 by 31 December 2007. This commitment only applied to Achuar territories and the Corrientes River within it. The practice of dumping produced water into the territory of the Kichwa and Quechua indigenous people from the Pastaza and the Tigre rivers, who did not join the Achuar's strike, continued unabated until 2009. The oil company also agreed to pay approximately US\$10 million to implement the Health Action Plan designed by DIRESA in June 2006, a health care plan only for the Achuar people. Also, the other agreements contained in the accord addressed solely the Achuar, e.g., the development plan worth approximately US\$3 million, and the plan to provide food aid and renovate the potable water system. That is, the Kichwa and Quechua peoples were excluded from the concrete remediation activities that took place after the 2006 Achuar mobilization.

\section{The Topal Accords and beyond}

The Dorissa Accords and their implementation represented a turning point. The main source of pollution (dumping of produced water) came to an end through reinjection, and the pollution levels in the surface waters of the area decreased substantially (Yusta-García et al. 2017). However, there were still important issues to be solved, such as the remediation of polluted sites and the replacement of pipelines, which was overdue by over two decades and was the source of numerous oil leaks and spills. Furthermore, not all the promised actions of the Dorissa Accords were fulfilled: the US\$10 million Health Action Plan was not implemented and the hospital that was to be built in the area never materialized (Defensoría del Pueblo 2008, Orta-Martínez and Finer 2010). The development plan for the Corrientes River was similarly not carried out (Defensoría del Pueblo 2008, Bebbington and Bury 2013).

The Dorissa Accords were followed by another five-year cycle of inaction, search for dialogue, and protest. ${ }^{[5]}$ In this case, the Quechua indigenous leaders for months had meetings with the regional government, released public statements and press releases demanding government compliance with another agreement, signed in 2011, reiterating promises of health interventions and environmental restoration (Pastaza Accords, signed with the Regional Government of Loreto [GOREL] in May 2011). Concurrently, after intense lobbying by the indigenous federations, a working group of the Peruvian congress was set-up in September 2011 to evaluate the situation of the area (CPAAAAE 2012). The group was scheduled to travel to the Pastaza in May 2011, but the trip was suddenly called off, sparking Quechua protests along the Pastaza River. During a week-long protest, Quechua communities converged on the indigenous village of Alianza Topal and were ready to occupy the company's grounds. President Humala's administration dispatched top government officials to the Pastaza, including the Minister of Health, Mr. Alberto Tejada, and the Minister for the Environment, Mr. Pulgar (PUINAMUDT 2012). Several meetings took place in Topal, including those with the ministers, but also with the President of GOREL, Mr. Ivan Vásquez. The turmoil ended peacefully with yet another commitment by the Peruvian government, known as the Topal Accords, to immediately form a new multisector commission to investigate oil contamination and launch a comprehensive health program within a month (Comisión de Justicia y Derechos Humanos 2013). 
The new promises focused not just on the Pastaza but included residents of all four river basins. In fact, Achuar and KukamaKukamilla leaders from FECONACO and ACODECOSPAT also travelled to the Pastaza and signed the Topal Accords. The inclusion of all indigenous group in the agreement was a result of a new strategy employed by the indigenous organizations: since 2011 the Achuar, Quechua, Kichwa, and Kukama-Kukamilla federations organized themselves into a joint political movement, PUINAMUDT (Indigenous Peoples United in the Defense of their Territories, for their acronym in Spanish). A unified organization overcame the history of antagonism between indigenous groups and was expected to be more effective in representing collective interests.

The Topal Accords can be considered the second turning point in the conflict after the Dorissa Accords. In 2013, as a consequence of the striking results of the environmental analysis conducted by different governmental agencies within the framework of the investigation of oil pollution agreed in the Topal Accords, the Peruvian government declared a state of environmental emergency in the whole Pastaza, Corrientes, Tigre, and Marañón river basins (see Ministerial Resolution 094-2013-MINAM, Ministerial Resolution 263-2013-MINAM, and Ministerial Resolution 370-2013-MINAM). In May 2014, the Peruvian government also declared a health emergency in the four river basins (see Supreme Decree 006-2014-SA). The declarations of emergency established immediate action plans, with a set of 16 concrete actions to be carried out in a period of 90 days, such as the construction of water treatment plants to provide safe drinking water to the indigenous communities.

However, and at this stage unsurprisingly, the action plans included in the states of emergency were not implemented by the Peruvian government and the Peruvian Ombudsman issued, in January 2014, a press release urging the government to take immediate action (Defensoría del Pueblo 2014). The indigenous federations were prompted to resort again to the most disruptive instrument at their disposal: occupation of the company's operations to stop oil extraction. Thus, in June 2014, a year after the declaration of the environmental emergency and two months after the declaration of the health emergency, 1500 indigenous people converged outside the oil production facility of Andoas for 18 days, threatening to stop the operation of the oil wells unless concrete steps were undertaken by the government to execute existing agreements (PUINAMUDT 2014). The protest ended with a new deadline of three months to comply with the action plans of the states of emergency. The first water treatment plant, stipulated in the declarations of emergency, was finally in use in March 2015 (TVPerú 2015).

The effectiveness of open conflict as a way to secure the interests of indigenous communities was tested again in 2015. In the frame of a third multisector commission, new accords were signed between PUINAMUDT and the Peruvian government, to conduct an epidemiological study to evaluate the health situation in the area, to implement a US\$3 million health care system for the whole area, to remediate the oil-polluted sites with a US\$15 million fund (FONAM) ${ }^{[6]}$, and to title the indigenous territories (Accords of 10 March 2015). However, once again, the failure to implement part of the agreements led to a wave of social unrest. In September 2015, the indigenous communities occupied and blocked the operations of all the oil wells in block 192 for 15 days, until the signature of the Teniente López Accords with a new commitment to implement the Accords of 10 March 2015 (PUINAMUDT 2015a). In November 2015, the epidemiological pilot study, promised first in 2006, finally started (La Región 2015); in December 2015, a US\$1 million budget to complete the land titling that started in 1978 was approved ${ }^{[7]}$ (PUINAMUDT $2015 b)$.

The occupation of oil wells, which is the most direct form of conflict in extraction areas, has proved to be instrumental to ensure the rights of indigenous people. Recently, the indigenous communities have also used this method to effectively claim economic compensation for the use of and damage to their lands. From 28 October to 1 November 2014, Quechua indigenous people occupied the company airport in Andoas; in January 2015 the Kichwa blockaded the Tigre River for a month, not allowing any boat belonging to the company to cross; between January and April 2015, the Achuar stopped oil extraction in 20 oil wells in Dorissa and Jibarito for two months. All these actions ended with the payment by the company of unspecified financial compensation to local communities.

\section{Epilogue: the price of success?}

Throughout this article we have presented the severe environmental and health effects of oil extraction in the northern Peruvian Amazon. The chronicle of corporate abuses and subsequent attempts by local indigenous people for redress suggests that conflict is a necessity to improve operational standards and mitigate oil-related pollution and its consequences.

These victories and improvements of operational practices were often followed by reprisals from the corporations. In 1991, when FECONACO was founded, OXY halted air transportation services for indigenous people in case of health emergencies (La Torre López 1998). Furthermore, OXY resorted to a combination of threats and bribes to indigenous leaders to weaken resistance (Bebbington and Bury 2013). When in the 2000s, indigenous organizations became increasingly vocal, Pluspetrol supported the creation of a new indigenous organization, FEPIBAC (Isla 2009, Lu 2009, Orta-Martínez and Finer 2010). This has also happened in other oil extraction areas in the Amazon "both to deal with and undermine local territorial claims" (GuzmánGallegos 2012:173). Companies' strategies to undermine opposition to oil operations worsened after the Dorissa Accords. After the local indigenous population halted oil extraction in the area for the first time, the first author directly observed Pluspetrol's barges that are normally used for transporting materials carrying large amounts of alcoholic beverages that were gifted to several indigenous communities (Fig. 2). Alcoholism among indigenous people suddenly and unsurprisingly increased, spreading domestic violence and, most likely, increasing mortality from hepatic cirrhosis in a highly endemic area of hepatitis B (DGE 2006). The author also collected several testimonies of bribes of indigenous leaders with prostitutes and alcohol. As a consequence of these tactics, after the Dorissa Accords, organizations such as FECONACO were weakened, its leaders got entangled with accusations of corruption and secret dealings with the oil company and lost political power. Furthermore, a new organization in the Pastaza River, ORIAP, was created 
seemingly with the support of the oil companies. The goal seems to have been to further override the resistance of existing indigenous organizations (now working together as PUINAMUDT) within the framework of free, prior, and informed consent regulations covering the leasing of a new oil block. PUINAMUDT denounced the creation of this astroturf organization, its recognition by the state, as well as the rise in social tensions in their communities engendered by this latest attempt to erode indigenous agency (PUINAMUDT 2015c, 2016). In this context, on 2 May 2016, the Quechua indigenous leader Aurelio Chino Dahua was the victim of what seems to have been an assassination attempt, which he survived.

Fig. 2. Pictures of a Pluspetrol's barge, named Camisea (from the name of the most important gas concession in Peru that is also operated by Pluspetrol), carrying large amounts of cases of beer that were gifted to several indigenous communities (Corrientes River, 14 October 2008).

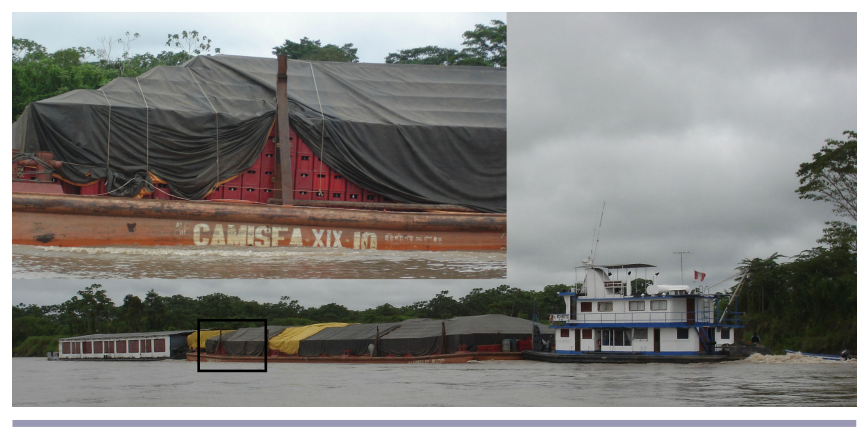

CONCLUSIONS: GREASING THE SQUEAKY WHEEL?

Despite the early identification of environmental and health risks for the indigenous population living in the surrounding areas of the oil blocks $1 \mathrm{AB} / 192$ and 8 , none of the state-based judicial and nonjudicial mechanisms were able to guarantee their rights. State inaction and ineffectiveness and the continuation of unsafe and insufficient operational standards led to a severe health situation that resulted, almost 30 years after the first identification of alarming oil-related pollution, in the declaration, by the Peruvian government, of the environmental and health emergency in the whole area in 2013 and 2014. However, even these drastic state mechanisms failed to protect indigenous health and improve their situation. Neither cutting edge technologies, improved regulations and standards, nor mitigation actions were implemented in these areas until recently. Whether this was because of corruption, double standards, cost-cutting, lack of state oversight capacities, or ineffectiveness of the sanction procedures is immaterial. What is clear, also from numerous other observations in the region, is that this has been the norm for extractive industries in Latin America (and many other parts of the world) where governments are experiencing and contributing to an "extractive imperative" (Arsel et al. 2016, Pellegrini 2018). Indigenous communities experience this "business model" in terms of environmental injustice that can be called silent, structural, or slow violence.

The chronicles of indigenous activism in the northern Peruvian Amazon demonstrate that a significant strategy that has brought meaningful redress to this injustice has been direct, open conflict that threatened the operation of the oil economy in the region. Escalating conflict has been effective in boosting changes of the operational procedures and standards and improving socioenvironmental performance of the oil companies operating in the area: from produced water reinjection, changes of environmental standards in the Peruvian legislation, improvement of monitoring schemes, remediation of oil-polluted sites, implementation of drinking water treatment plants and health care plans, to land titling, payment of the easement right, and redistribution of the royalties. This is in keeping with the observations that "[f]eeling that there are few or no possibilities to elicit government response to their concerns, local populations frequently conclude that violent conflict is the only way to make their knowledge count" (Bebbington and Bury 2009:17299) and that "conflicts can be seen not as problems that have to be resolved quickly but rather as motors that drive institutional transformations" (Bebbington and Bebbington 2009:117). This is, of course, not unique to this particular moment in history or to the Peruvian Amazon. Progress has often been a result of such conflicts, and many contemporary institutions that help maintain social order and peace have been the result of collective public actions, riots, petitions, peaceful marches, strikes, boycotts, community consultation, and everyday forms of resistance, that can provoke a crisis before ultimately creating a new, improved status quo (Scott 1985). We therefore argue that, under certain circumstances, conflict is the sole mechanism that is left to local communities to effectively promote institutional and business transformations and foster better environmental performance and compliance with human rights.

The paper therefore argues that there exists a "conflict imperative," one that compels communities such as those discussed in this paper to abandon bureaucratic procedures and nonserious dialogue in order to secure expedient solutions to their concerns. The hypothesis that the choice of open conflict can be productive for communities affected by extractive industries could be tested more systematically in Latin America and beyond using a variety of methodological approaches, including large-n studies and historical case studies such as the one presented here. Further study of this conflict-dialogue dynamic would contribute to a better understanding of the relationship between natural resources and processes of conflict and cooperation as they occur in the Global South.

The corollary of this hypothesis is that dialogue is sometimes neither peaceful nor useful for affected communities. In fact, long and drawn-out bureaucratic procedures, negotiations, and attempts of various actors to pass the responsibility of action between each other, e.g., between different levels of government, can all add up to a form of violence, not only in the physical sense, e.g., through health impacts, but also socially, culturally, and psychologically. Seen from this perspective, the alternative to open conflict might not be peaceful dialogue but insidious neglect.

Nevertheless, it is important to problematize the observation that only a squeaky wheel gets the grease. First, to call for intensified resistance and open conflict can be a rather facile strategy. As mentioned earlier, there are historical antecedents to the decision of the Achuar, who are generally believed to have a strong cultural identity and organizational strength, that enabled them to mobilize earlier than the other indigenous groups in the region. 
Even in the case of the Achuar, it is clear that the decision to escalate the conflict was neither quick nor automatic and came decades into their experience with extractive industries and dialogue attempts. In short, under the mentioned circumstances, i.e., state inaction and company intentional malpractice, the ability to engage in conflict-dialogue cycles could be itself a capability that is not uniformly present in all contexts. This is an analytically fertile observation that requires further research to understand when and how the capability to escalate existing disagreements could be constructed (Arsel et al. 2015).

Second, the paper has so far asserted that the Achuar decision to engage in open conflict (and alternate it with dialogue attempts) has been a success. The evidence from this comes from the decision of corporate and state actors to, grudgingly and at a glacial pace, take steps to diminish the environmental injustices experienced by indigenous communities. However, this success has certainly exacted a heavy price. The deliberately inflicted social and health impacts of alcohol abuse or the attempt at the life of an indigenous leader are only the easily visible and spectacular demonstrations of the cost of fighting back, in a context of increasing violence against environmental human rights defenders in Latin America. Beyond these are myriad other damages, be they financial, cultural, or psychological, that come from living in a heightened state of conflict. In most cases, the longer such conflicts last, the higher the uncertainty and the more grave the negative impacts of partaking in them even if there are objective signs of success.

Another way of questioning the meaning of success concerns the idiom of the "squeaky wheel gets the grease," which suggests implicitly that the wheel keeps turning. On the one hand, conflicts such as the one analyzed here are hugely important because oil exploitation activities have been identified as the cause of severe health impacts and social problems to local communities. In a context of growing global demand in oil, from 85.3 million barrels per day in 2006 to 92.1 million barrels per day in 2014 (British Petroleum 2015) that has stimulated a renewed growth in hydrocarbons concessions in the region (Finer et al. 2008, Finer and Orta-Martínez 2010), even a modest definition of success is important as part of attempts to minimize potential social and ecological damages associated with the operation of extractive industries. On the other, it is important to recognize also that the continued turning of the wheel in this case, of course, refers to the continued operation of oil exploration in the Amazon. Even if the concerns of the Achuar, as well as the Quechua and the Kichwa, were to be fully met, it is not entirely certain that the continued operation of oil exploration in the Amazon can be categorized as a success. Among many others, the impact of oil exploration on the global climate might necessitate the questioning of calls to make oil extraction more sustainable at the local level (Pellegrini et al. 2014, Martinez-Alier 2015, Vira 2015).

If the second caveat necessitates that we take a more nuanced understanding of success, the third and final one calls for a rethinking of the boundaries between conflict and negotiation. The story we have chronicled in this paper is one that spans decades and is clearly far from conclusion. Within such a temporal framework, it might be necessary to think of conflict not as a distinct outcome that differs fundamentally from the state of peace and negotiation. Rather than an outcome of the failure of negotiation, conflict is a recurrent leitmotif in this story, one that indigenous communities choose to introduce at strategic moments. In our chronicle, conflict itself was often the antecedent to a new round of dialogue and negotiation made possible by the presence of government officials purposively and urgently dispatched to the area. In other words, just as von Clausewitz had argued that "war is merely the continuation of policy by other means" (von Clausewitz 2007:28), indigenous decisions to occupy, blockade, and disrupt the working of oil operations might tentatively be understood as a similar attempt to continue negotiating with the state and corporations by using other tools they have at their disposal.

${ }^{[1]}$ Produced water can contain a number of potentially toxic agents, including radioactive isotopes, dispersed hydrocarbons (i.e., phenolic and polyaromatic molecules among others), and heavy metals (i.e., cadmium, chromium, lead, and barium among others; Fakhru'l-Razi et al. 2009). The practice of injecting produced water in oil fields dates back to the late 19th century and was developed to improve oil recovery by maintaining reservoir pressure (Satter et al. 2008). Before the 1970s, U.S. regulations for the oil industry limited or prohibited entirely the practice of discharging produced water onto land or surface waters. In onshore areas, the first suggested option is their reinjection back into the oil wells (RCT 1964, E\&P Forum 1989, 1991).

[2] According to Peruvian law from 1993 (DS-046-93-EM), production waters "should preferably be reinjected," although it allowed its dumping under some conditions. When the Achuar blocked the oil wells in October 2006, the reinjection of all production waters was an obligation according to the Peruvian Law dating March 2006(DS-15-2006-EM), but oil blocks 1AB/192 and 8 were exempted from this provision. The law from 1993 required an Environmental Adjustment and Management Program (PAMA) for running operations so that they would gradually comply with the new obligations. The PAMAs for blocks $1 \mathrm{AB} / 192$ and 8 , that were approved in 1996 and had to be implemented before 2002, did not include the reinjection of produced water. In any case, Pluspetrol did not comply with the PAMAs, and was granted an extension until 2008 to present a new Complementary Environmental Plan (PAC; DS-028-2003-EM). The PACs for blocks $1 \mathrm{AB} / 192$ and 8, which were approved in 2005 (RD 0153-2005-MEM/AAE), did not include the reinjection of the produced water either.

${ }^{[3]}$ Investigation file 00018-2015-0-1901-JM-CI-01.

${ }^{[4]}$ The publication of the report, nearly a year after the time the samples were collected, required the presentation of notarized letters to the Minister of Health, Dr Pilar Mazetti Soler.

${ }^{[5]}$ Another conflict in the area took place on 20 March 2008, in Andoas. Although the conflict focused on the oil industry and escalated (one policemen was killed and 48 indigenous leaders incarcerated) we are not focusing on this event. This choice is because, although the conflict was rooted in various grievances (including environmental ones), tense labor relations between community members and the oil company also played a major role in triggering it.

${ }^{[6]}$ Ley $N^{\circ}$ 30321: Ley que crea el Fondo de Contingencia para Remediación Ambiental. http://www4.congreso.gob.pe/pvp/leyes/ ley30321.pdf

${ }^{[7]}$ Public Investment Project N²262233 “Ampliación del Servicio de Catastro, Titulación y Registro de Tierras en las Comunidades Nativas de las Cuencas de los Ríos Pastaza, Tigre, Corrientes y 
Marañón, de la Provincia de Datem del Marañón y Loreto, Región Loreto."

Responses to this article can be read online at: http://www.ecologyandsociety.org/issues/responses. php/10098

\begin{abstract}
Acknowledgments:
We are grateful for the support of local indigenous communities and the indigenous federations of the Pastaza and Corrientes River basins (FEDIQUEP and FECONACO, respectively) over these years. We also appreciate the financial support of the Conflict and Cooperation over Natural Resources in Developing Countries program of The Netherlands Organisation for Scientific Research (NWO; https://www.iss.nllen, and the International Initiative for Impact Evaluation (3ie).
\end{abstract}

\section{LITERATURE CITED}

AIDESEP and Rainforest Foundation US. 2015. Peru at the climate crossroads. Rainforest Foundation US, New York, New York, USA. [online] URL: http://www.burness.com/wp-content/ uploads/2015/11/Peru_at the Climate_Crossroads.pdf

Álvarez-Alonso, J. 2008. Perú: Los sobrevivientes. Servindi, Lima, Peru. [online] URL: https://www.servindi.org/actualidad/ cronica/5163

Arsel, M. 2011. Fuelling misconceptions: UNEP, natural resources, the environment and conflict. Development and Change 42(1):448-457. http://dx.doi.org/10.1111/j.1467-7660.2011.01684. $\underline{x}$

Arsel, M., B. Akbulut, and F. Adaman. 2015. Environmentalism of the malcontent: anatomy of an anti-coal power plant struggle in Turkey. Journal of Peasant Studies 42(2):371-395. http://dx.doi. org/10.1080/03066150.2014.971766

Arsel, M., and B. Büscher. 2012. Nature ${ }^{\mathrm{TM}}$ Inc.: changes and continuities in neoliberal conservation and market-based environmental policy. Development and Change 43(1):53-78. http://dx.doi.org/10.1111/j.1467-7660.2012.01752.x

Arsel, M., B. Hogenboom, and L. Pellegrini. 2016. The extractive imperative in Latin America. Extractive Industries and Society 3 (4):880-887. http://dx.doi.org/10.1016/j.exis.2016.10.014

Auty, R. M. 2002. Sustaining development in mineral economies: the resource curse thesis. Taylor \& Francis, London, UK. http:// dx.doi.org/10.4324/9780203422595

Bebbington, A., and D. H. Bebbington. 2009. Actores y ambientalismos: conflictos socio-ambientales en Perú [Actors and environmentalism: socio-environmental conflicts in Peru]. Íconos. Revista de Ciencias Sociales(35):117-128.

Bebbington, A. J., and J. T. Bury. 2009. Institutional challenges for mining and sustainability in Peru. Proceedings of the National Academy of Sciences 106(41):17296-17301. http://dx.doi. org/10.1073/pnas.0906057106
Bebbington, A., and J. Bury. 2013. Subterranean struggles: new dynamics of mining, oil, and gas in Latin America. University of Texas Press, Austin, Texas, USA.

British Petroleum. 2015. BP statistical review of world energy June 2015. [online] URL: https://www.bp.com/content/dam/bpcountry/es es/spain/documents/downloads/PDF/bp-statistical-reviewof-world-energy-2015-full-report.pdf

Cánepa, J., R. Pezo, and H. Paredes. 1987. Proyecto contaminación ambiental en la amazonía peruana. Estudio hidrobiológico del río Corrientes. Instituto de Investigaciones de la Amazonía Peruana, Iquitos, Peru.

Comisión de Amazonía, Asuntos Indigenas y Afroperuanos del Congreso de la República del Perú (CAAIA). 2005. Informe de la gestión correspondiente al periodo legislativo 2004 - 2005. Lima, Peru.

Comisión de Justicia y Derechos Humanos. 2013. Vulneración de derechos fundamentales de los pueblos amazónicos asentados en las cuencas de los ríos Pastaza, Tigre, Corrientes y Marañón. Comisión de Justicia y Derechos Humanos, Lima, Peru.

CPAAAAE. 2012. Informe Final sobre la Situación Indígena de las Cuencas de los ríos Tigre, Pastaza, Corrientes y Marañón. CPAAAAE, Lima, Peru.

Defensoría del Pueblo. 2008. Nota de Prensa 137/CII/DP/2008. Balance de cumplimiento del Acta de Dorissa. Defensoría del Pueblo advierte incumplimiento de compromisos port parte del Estado. Defensoría del Pueblo, Lima, Peru.

Defensoría del Pueblo. 2014. Nota de Prensa $N^{o} 013 / D P /$ OCII/2014. Ante contaminación ambiental en cuencas de los ríos Pastaza, Tigre y Corrientes, la Defensoría del Pueblo recomienda cumplir compromisos derivadors de los planes de emergencia ambiental en Loreto. Defensoría del Pueblo, Lima, Peru.

Dirección General de Epidemiología (DGE). 2006. Análisis de situación de salud del Pueblo Achuar. DGE, Ministerio de Salud, Lima.

Dirección General de Salud Ambiental (DIGESA). 2006. Evaluación de resultados del monitoreo del río Corrientes y toma de muestras biológicas, en la intervención realizada del 29 de junio al 15 de julio del 2005. Informe No-2006/DEPA-APRHI/ DIGESA. DIGESA, Ministerio de Salud, Lima, Peru.

E\&P Forum. 1989. Treatment of production water: a review of current performance. Report No. 2. 29/111. E\&P Forum, London, $\mathrm{UK}$.

E\&P Forum. 1991. Oil industry operating guideline for tropical rainforests. Report No. 2.49/170. E\&P Forum, London, UK.

Fakhru'l-Razi, A., A. Pendashteh, L. C. Abdullah, D. R. A. Biak, S. S. Madaeni, and Z. Z. Abidina. 2009. Review of technologies for oil and gas produced water treatment. Journal of Hazardous Materials 170(2-3):530-551. http://dx.doi.org/10.1016/j. jhazmat.2009.05.044

FECONACO (Achuar Federation of Native Communities of the Corrientes River). 2005a. Memorial de los pueblos Achuar, Quichua y Urarina del río Corrientes de la Asamblea del 6 de mayo de 2005. Belén de Plantanoyacu. FECONACO, Iquitos, Peru 
FECONACO (Achuar Federation of Native Communities of the Corrientes River). 2005b. Pronunciamiento de Belén de Plantanoyacu del 17 de noviembre del 2005: ;FECONACO dice no más actividades petroleras en su territorio! Federación de Comunidades Nativas del Río Corrientes, Belén de Plantanoyacu. FECONACO, Iquitos, Peru

FECONACO (Achuar Federation of Native Communities of the Corrientes River). 2005c. Indígenas amazónicos y su lucha contra las petroleras. Statement June 20th 2005. FECONACO, Iquitos, Peru

FECONACO (Achuar Federation of Native Communities of the Corrientes River). 2006. Statement October 4th 2006. FECONACO, Iquitos, Peru.

Finer, M., C. N. Jenkins, S. L. Pimm, B. Keane, and C. Ross. 2008. Oil and gas projects in the western Amazon: threats to wilderness, biodiversity, and indigenous peoples. PLOS ONE 3(8):e2932. http://dx.doi.org/10.1371/journal.pone.0002932

Finer, M., and M. Orta-Martínez. 2010. A second hydrocarbon boom threatens the Peruvian Amazon: trends, projections, and policy implications. Environmental Research Letters 5(1):14012. http://dx.doi.org/10.1088/1748-9326/5/1/014012

Fisher, R., and W. Ury. 2011. Getting to yes: negotiating agreement without giving in. Penguin Books, New York, New York, USA.

Fletcher, R. 2010. Neoliberal environmentality: towards a poststructuralist political ecology of the conservation debate. Conservation and Society 8(3):171-181. http://dx.doi. org/10.4103/0972-4923.73806

Galtung, J. 1969. Violence, peace, and peace research. Journal of Peace Research 6(3):167-191. http://dx.doi.org/10.1177/0022343$\underline{36900600301}$

Guzmán-Gallegos, M. A. 2012. The governing of extraction, oil enclaves, and indigenous responses in the Ecuadorian Amazon. Pages 155-176 in H. Haarstad, editor. New political spaces in Latin American natural resource governance. Palgrave Macmillan, New York, New York, USA. http://dx.doi.org/10.1057/9781137073723 8

Hirschman, A. O. 1994. Social conflicts as pillars of democratic market society. Political Theory 22(2):203-218. http://dx.doi. org/10.1177/0090591794022002001

Hurtig, A.-K., and M. San Sebastián. 2002. Geographical differences in cancer incidence in the Amazon basin of Ecuador in relation to residence near oil fields. International Journal of Epidemiology 31(5):1021-1027. http://dx.doi.org/10.1093/ije/31.5.1021

Hurtig, A.-K., and M. San Sebastián. 2004. Incidence of childhood leukemia and oil exploitation in the Amazon basin of Ecuador. International Journal of Occupational And Environmental Health 10(3):245-250. http://dx.doi.org/10.1179/ oeh.2004.10.3.245

Instituto del Bien Común. 2016. Sistema de Información sobre Comunidades Nativas de la Amazonía Peruana (SICNA). Instituto del Bien Común, Peru. [online] URL: http://www. ibcperu.org/mapas/sicnal

Isla, A. 2009. The eco-class-race struggles in the Peruvian Amazon Basin: an ecofeminist perspective. Capitalism Nature Socialism 20(3):21-48. http://dx.doi.org/10.1080/10455750903215720
Jobin, W. 2003. Health and equity impacts of a large oil project in Africa. Bulletin of the World Health Organization 81:420-426.

Keck, M. E., and K. Sikkink 1999. Transnational advocacy networks in international and regional politics. International Social Science Journal 51(159):89-101. http://dx.doi. org/10.1111/1468-2451.00179

Kriesberg, L. 1973. The sociology of social conflicts. Prentice-Hall, Englewood Cliffs, New Jersey, USA.

La Región. 2015. Desde el lunes intervendrán en cuencas afectadas por contaminación de metales pesados. La Región, 4 November. [online] URL: https://diariolaregion.com/web/desdeel-lunes-intervendran-en-cuencas-afectadas-por-contaminacionde-metales-pesados/

La Torre López, L. 1998. Sólo queremos vivir en paz! Experiencias petroleras en territorios indígenas de la Amazonía Peruana. Grupo Internacional de Trabajo Sobre Asuntos Indígenas (IWGIA); Grupo de Trabajo Racímos de Ungurahui, Copenhagen, Denmark.

Lu, G. M. M. 2009. The Corrientes River case: indigneous people's mobilization in response to oil development in the Peruvian Amazon. Thesis. University of Oregon, Eugene, Oregon, USA.

Maco, J., R. Pezo, and J. Cánepa. 1985. Seminario Contaminación por actividades petroleras en zonas tropicales. Contaminación ambiental por actividades petroleras - Fase producción. Instituto de Investigaciones de la Amazonía Peruana, Iquitos, Peru.

Martínez-Alier, J. 2002. The environmentalism of the poor: a study of ecological conflicts and valuation. Edward Elgar, Cheltenham, UK. http://dx.doi.org/10.4337/9781843765486

Martinez-Alier, J. 2015. Climate justice. Development and Change 46(2):381-386. http://dx.doi.org/10.1111/dech.12150

Ministerio de Energía y Minas (MEM). 1998. Evaluación ambiental Territorial de las Cuencas de los ríos Tigre-Pastaza. MEM, Lima, Peru.

Ministerio de Energía y Minas (MEM). 2014. Anuario Estadístico de Hidrocarburos. Dirección General de Hidrocarburos, MEM, Lima, Peru.

Muradian, R., J. Martinez-Alier, and H. Correa. 2003. International capital versus local population: the environmental conflict of the Tambogrande mining project, Peru. Society \& Natural Resources 16(9):775-792. http://dx.doi.org/10.1080/089$\underline{41920309166}$

Nixon, R. 2011. Slow violence and the environmentalism of the poor. Harvard University Press, Cambridge, Massachusetts, USA. http://dx.doi.org/10.4159/harvard.9780674061194

O’Callaghan-Gordo, C., M. Orta-Martínez, and M. Kogevinas. 2016. Health effects of non-occupational exposure to oil extraction. Environmental Health 15(1):56. http://dx.doi. org/10.1186/s12940-016-0140-1

Organismo Supervisor de la Inversión en Energía (OSINERG). 2004. Informe Lotes 1-AB y 8. Respuesta al Oficio No 0075-2004JDC/CR del Congreso de la República. Gerencia de Fiscalización en Hidrocaraburos, OSINERG, Lima, Peru. 
Organismo Supervisor de la Inversión en Energía y Minería (OSINERGMIN). 2009. Eliminación del mayor Impacto Ambiental de los Campos Petroleros. OSINERGMIN, Lima, Peru.

Orta-Martínez, M., and M. Finer. 2010. Oil frontiers and indigenous resistance in the Peruvian Amazon. Ecological Economics 70(2):207-218. http://dx.doi.org/10.1016/j. ecolecon.2010.04.022

Orta-Martínez, M., D. A. Napolitano, G. J. MacLennan, C. O'Callaghan, S. Ciborowski, and X. Fabregas. 2007. Impacts of petroleum activities for the Achuar people of the Peruvian Amazon: summary of existing evidence and research gaps. Environmental Research Letters 2(4):45006. http://dx.doi. org/10.1088/1748-9326/2/4/045006

Orta-Martínez, M., A. Rosell-Melé, M. Cartró-Sabaté, C. O'Callaghan-Gordo, N. Moraleda-Cibrián, and P. Mayor. 2018. First evidences of Amazonian wildlife feeding on petroleumcontaminated soils: a new exposure route to petrogenic compounds? Environmental Research 160:514-517. http://dx.doi. org/10.1016/j.envres.2017.10.009

Papyrakis, E., and R. Gerlagh. 2004. The resource curse hypothesis and its transmission channels. Journal of Comparative Economics 32(1):181-193. http://dx.doi.org/10.1016/i.jce.2003.11.002

Pellegrini, L. 2012. Planning and natural resources in Bolivia: between rules without participation and participation without rules. Journal of Developing Societies 28(2):185-202. http://dx.doi. org/10.1177/0169796X12448757

Pellegrini, L. 2018. Imaginaries of development through extraction: the 'history of Bolivian petroleum' and the present view of the future. Geoforum 90:130-141. http://dx.doi. org/10.1016/j.geoforum.2018.01.016

Pellegrini, L., M. Arsel, F. Falconí, and R. Muradian. 2014. The demise of a new conservation and development policy? Exploring the tensions of the Yasuní ITT Initiative. Extractive Industries and Society 1(2):284-291. http://dx.doi.org/10.1016/j.exis.2014.05.001

Pellegrini, L., and M. O. Ribera Arismendi. 2012. Consultation, compensation and extraction in Bolivia after the 'left turn': the case of oil exploration in the north of La Paz Department. Journal of Latin American Geography 11(2):103-120. http://dx.doi. org/10.1353/lag.2012.0045

Pueblos Indígenas Amazónicos Unidos en Defensa de sus Territorios (PUINAMUDT). 2012. Hoy se instala Mesa de Diálogo entre pueblos indígenas de Loreto y el gobierno central. Press release. PUINAMUDT, Iquitos, Peru.

Pueblos Indígenas Amazónicos Unidos en Defensa de sus Territorios (PUINAMUDT). 2014. En su segunda visita en Andoas, Premier asume nuevos compromisos con comunidades Quechuas del Pastaza. Press release. PUINAMUDT, Iquitos, Peru.

Pueblos Indígenas Amazónicos Unidos en Defensa de sus Territorios (PUINAMUDT). 2015a. Acta de Teniente López. Teniente López. PUINAMUDT, Iquitos, Peru.

Pueblos Indígenas Amazónicos Unidos en Defensa de sus Territorios (PUINAMUDT). 2015b. Organizaciones indigenas y
Gobierno Regional de Loreto firman convenio para titular comunidades nativas. Press Release. PUINAMUDT, Iquitos, Peru. [online] URL: http://observatoriopetrolero.org/organizacionesindigenas-y-gobierno-regional-de-loreto-firman-convenio-para-titularcomunidades-nativas/

Pueblos Indígenas Amazónicos Unidos en Defensa de sus Territorios (PUINAMUDT). 2015c. Pronunciamiento de las familias afectadas por discriminación y agresión de la comunidad nativa Los Jardines y Los Vencedores del Pastaza por parte de la ONG ORIAP. PUINAMUDT, Iquitos, Peru.

Pueblos Indígenas Amazónicos Unidos en Defensa de sus Territorios (PUINAMUDT). 2016. Press Release. PUINAMUDT, Iquitos, Peru.

Radio Oriente. 2011. Achuar del Pastaza presentan al Congreso pedido para reconocimiento de territorio integral. Radio Oriente, Loreto, Peru. [online] URL: http://www.roriente.org/2011/09/20/ achuar-del-pastaza-presentan-al-congreso-pedido-para-reconocimientode-territorio-integral/

Railroad Commission of Texas (RCT). 1964. Current rules: Texas administrative code (TAC) Title 16. Economic regulation Part 1. Railroad Commission of Texas. (Effective 1 July 1964, amended 1 July 1967). RCT, Austin, Texas, USA. [online] URL: http://www. rrc.texas.gov/general-counsel/rules/current-rules/

Robinson, J. A., R. Torvik, and T. Verdier. 2014. Political foundations of the resource curse: a simplification and a comment. Journal of Development Economics 106:194-198. http:// dx.doi.org/10.1016/j.jdeveco.2013.09.004

Rosell-Melé, A., N. Moraleda-Cibrián, M. Cartró-Sabaté, F. Colomer-Ventura, P. Mayor, and M. Orta-Martínez. 2018. Oil pollution in soils and sediments from the northern Peruvian Amazon. Science of The Total Environment 610-611:1010-1019. http://dx.doi.org/10.1016/j.scitotenv.2017.07.208

San Sebastián, M., B. Armstrong, J. A. Córdoba, and C. Stephens. 2001. Exposures and cancer incidence near oil fields in the Amazon basin of Ecuador. Occupational and Environmental Medicine 58(8):517-522. http://dx.doi.org/10.1136/oem.58.8.517

San Sebastián, M., B. Armstrong, and C. Stephens. 2002. Outcomes of pregnancy among women living in the proximity of oil fields in the Amazon basin of Ecuador. International Journal of Occupational and Environmental Health 8(4):312-319. http:// dx.doi.org/10.1179/107735202800338650

Satter, A., G. M. Iqbal, and J. L. Buchwalter. 2008. Practical enhanced reservoir engineering: assisted with simulation software. PennWell Books, Tulsa, Oklahoma, USA.

Schilling-Vacaflor, A., and J. Eichler. 2017. The shady side of consultation and compensation: 'divide-and-rule' tactics in Bolivia's extraction sector. Development and Change 48 (6):1439-1463. http://dx.doi.org/10.1111/dech.12345

Scott, J. 1985. Weapons of the weak: everyday forms of peasant resistance. Yale University Press, New Haven, Connecticut, USA.

Scurrah, M. 2013. Hydrocarbon conflicts and indigenous peoples in the Peruvian Amazon: mobilization and negotiation along the Río Corrientes. Pages 173-196 in A. Bebbington and J. Bury, editors. Subterranean struggles: new dynamics of mining, oil, and 
gas in Latin America. University of Texas Press, Austin, Texas, USA.

Servindi. 2014. Los Achuar: primer pueblo indígena en Perú que demanda titulación integral de su territorio. Servindi, Lima, Peru. [online] URL: http://www.servindi.org/actualidad/115781

Siegel, K. M. 2016. Fulfilling promises of more substantive democracy? Post-neoliberalism and natural resource governance in South America. Development and Change 47(3):495-516. http:// dx.doi.org/10.1111/dech.12234

Silva, E. 2017. Pushing the envelope? Mega-projects, contentious action, and change. Research Group MEGA. Center for InterAmerican Policy and Research (CIPR), Tulane University, New Orleans, Louisiana, USA.

Stetson, G. 2012. Oil politics and indigenous resistance in the Peruvian Amazon: the rhetoric of modernity against the reality of coloniality. Journal of Environment \& Development 21(1):76-97. http://dx.doi.org/10.1177/1070496511433425

Stocks, A. 2005. Too much for too few: problems of indigenous land rights in Latin America. Annual Review of Anthropology 34 (1):85-104. http://dx.doi.org/10.1146/annurev.anthro.33.070203.143844

Surrallés, A., and P. Garcia-Hierro. 2004. Tierra Adentro. Territorio Indígena y Percepción del Entorno. Documento No. 39. International Work Group for Indigenous Affairs, Copenhagen, Denmark.

Swyngedouw, E. 2006. Power, water and money: exploring the nexus. Human Development Report 14. United Nations Development Programme, New York, New York, USA.

Tacitus. 2009. Agricola and Germany. Translation by Anthony Birley. Oxford University Press, Oxford, UK.

TVPerú. 2015. Pdte. Humala inauguró planta potabilizadora de agua en comunidad nativa de Loreto. [TV News Report.] TVPerú, 14 March. [online] URL: http://www.tvperu.gob.pe/informa/ politica/pdte-humala-inaugur-planta-potabilizadora-de-agua-encomunidad-nativa-de-loreto

United Nations. 2007. United Nations Declaration on the Rights of Indigenous Peoples. United Nations, New York, New York, USA.

Uriarte, L. M. 2007. Los Achuar. Page 390 in F. Santos and F. Barclay, editors. Guía etnográfica de la alta amazonía. Smithsonian Tropical Research Institute / Insituto Francés de Estudios Andinos, Lima, Peru.

Vira, B. 2015. Taking natural limits seriously: implications for development studies and the environment. Development and Change 46(4):762-776. http://dx.doi.org/10.1111/dech.12175

von Clausewitz, C. 2007. On war. Oxford University Press, New York, New York, USA.

Walker, G. 2009. Beyond distribution and proximity: exploring the multiple spatialities of environmental justice. Antipode 41 (4):614-636. http://dx.doi.org/10.1111/j.1467-8330.2009.00691.x

Watts, M. J. 2013. Silent violence: food, famine, and peasantry in northern Nigeria. University of Georgia Press, Athens, Georgia, USA.
Yusta-García, R., M. Orta-Martínez, P. Mayor, C. GonzálezCrespo, and A. Rosell-Melé. 2017. Water contamination from oil extraction activities in northern Peruvian Amazonian rivers. Environmental Pollution 225:370-380. http://dx.doi.org/10.1016/j. envpol.2017.02.063 